\title{
DEFENDING TRADITIONS, COUNTERING INTOLERANT IDEOLOGIES Re-energizing the Role of Modin in Modern Java ${ }^{1}$
}

\section{Achmad Zainal Arifin}

Sunan Kalijaga State Islamic University (UIN) Yogyakarta, Indonesia email:achmad.arifin@uin-suka.ac.id.

\section{Abstract}

This paper discusses a neglected traditional Islamic figure called modin, who actually bas potential and greater opportunity in countering the growing numbers of relatively new Islamic groups that perpetuate intolerant ideology. This paper is based on a fieldwork in the Village of Sidolubur, Godean, Sleman, DIY. The primary data used for this research is derived from in-depth interviews with 17 people such as modin, village offccers, mosques' board members, and active jamaah (members) of the mosques. I argue that modin has a significant contribution in softening tensions among Muslims at a hamlet level. He will be functioning effectively in preserving local Islamic practices and, at the same time, filtering intolerant ideology in society. In so doing, contestations among modin, who might come from various Islamic groups, have to be carefully considered to maximize his roles in society, especially in countering intolerant views proposed by some transnational Islamic groups.

[Artikel ini membahas peminggiran figur Islam tradisional di Jawa yang dikenal dengan sebutan modin. Figur ini sebenarnya mempunyai potensi dan peluang besar untuk menandingi perkembangan kelompok Islam yang menyebarkan ideologi intoleran. Artikel ini ditulis berdasarkan riset lapangan

1 This paper was presented at International Conference on Growing Religious Intolerance in Indonesia: Outlook, Challenges, and Future Trajectory of Indonesian Religious Life held by Pascasarjana UIN Sunan Kalijaga and Rajaratnam School of International Studies, Singapore in Yogyakarta (2015). 
di Desa Sidolubur, Godean, Yogyakarta, dengan melakukan wawancara mendalam terbadap tujuh belas informan meliputi modin, perangkat desa, pengurus masjid, dan jamaah masjid. Penelitian ini menunjukkan bahwa modin mempunyai kontribusi penting dalam meredam ketegangan umat di tingkat dusun. I a berperan dalam melestarikan praktik Islam lokal sekaligus menyaring ideologi intoleran dalam masyarakat. Adanya kontestasi di antara modin yang berasal dari kelompok yang berbeda perlu menjadi pertimbangan untuk. memaksimalkan peran modin di masyarakat dalam menandingi ideologi intoleran yang diusung oleh kelompok. Islam transnasional.]

Keywords: local tradition, modin, religious contestation, transnational Islam, religious intolerant

\section{A. Introduction}

Indonesian Islam in post-Reformation era shows growing numbers of religious violence across the country. ${ }^{2}$ Various religious violence, ranging from burning some public and religious facilities, including churches and mosques, to some physical intimidation such as in in the case of Ahmadiyah and Syiah communities, are undeniably caused by the literal and narrow understanding of religious doctrines. ${ }^{3}$ The downfall of the Suharto regime in 1998 gave an opportunity to some hardliner Islamic groups to move from their underground dakwah or proselytization ${ }^{4}$ to openly compete with other established Islamic groups, such as the Nahdlatul Ulama (commonly abbreviated as NU) and Muhammadiyah. Although some Islamic leaders from these mainstream Islam always claim for the insignificant numbers of the radical Islamic groups, ${ }^{5}$ but

${ }^{2}$ Endang Turmudi and M. Riza Sihbudi (eds.), Islam dan Radikalisme di Indonesia (Jakarta: LIPI Press, 2005); Bahtiar Effendy and Soetrisno Hadi (eds.), Agama dan Radikalisme di Indonesia (Jakarta: Nuqtah, 2007).

3 Marika Vicziany and David Wright-Neville (eds.), Islamic Terrorism in Indonesia: Myths and Realities (Clayton, Vict.: Monash University Press, 2006); Muhammad Asfar (ed.), Islam Lunak, Islam Radikal: Pesantren, Terorisme dan Bom Bali (Surabaya: Pusat Studi Demokrasi dan HAM (PuSDeHAM) and JP Press, 2003).

${ }^{4}$ Greg Barton, Indonesia's Struggle: Jemaah Islamiyah and the Soul of Islam (Sydney: UNSW Press, 2004).

${ }^{5}$ A. Rubaidi, Radikalisme Islam, Nabdlatul Ulama \& Masa Depan Moderatisme Islam Di Indonesia (Yogyakarta: Logung Pustaka, 2008). 
the statistics show a serious problem related to the increasing numbers of those who supported violence in the name of implementing the Islamic rule of conducts in society. ${ }^{6}$

This concern was shown in the survey on people's attitude toward intolerant activities conducted by Pusat Pengkajian Islam dan Masyarakat (Center for Islam and Society Studies or PPIM), UIN Syarif Hidayatullah Jakarta in 2011. The survey revealed that 60.4 percent of their respondents supported intolerant and violence actions. A year later, Setara Institute, another survey center, claimed that Indonesia was at a higher level of radicalism and terrorism with the index scale of 43.6 percent. At the same year, LaKIP also conducted a survey to students at 100 high-schools in Jakarta which claimed the high support for intolerant actions toward minorities and sympathetic feelings for the actors of violence. These statistical examples, along with other reports on religious violence, have been noted by Fealy as a phenomenon of 'conservative-turn' on a religious landscape on Indonesian Islam. ${ }^{7}$ This changing situation requires more serious attention, especially for the Indonesian government in adopting a new strategy in countering religious radicalization.

Some success stories on capturing terrorists, especially through some operations that have been conducted by the Densus $88^{8}$ and Badan Nasional Penanggulangan Terorisme ('National Agency for CounterTerrorism' or BNPT), ${ }^{9}$ might have been internationally recognized, but

${ }^{6}$ Haedar Nashir, Gerakan Islam Syari'at: Reproduksi Salafiyah Ideologis Di Indonesia (Jakarta: Pusat Studi Agama dan Peradaban Muhammadiyah, 2007); Muhammad Iqbal Ahnaf et al., Politik Lokal dan Konflik Keagamaan: Pilkada dan struktur kesempatan politik. dalam konflik keagamaan di Sampang, Bekasi, dan Kupang (Yogyakarta: Center for Religious \& Cross-Cultural Studies UGM, 2015).

7 Greg Fealy, "Islamic Radicalism in Indonesia: The Faltering Revival?", in Southeast Asian Affairs, vol. 2004 (Singapore: ISEAS-Yusof Ishak Institute, 2004).

8 Densus (Detasemen Khusus) 88 or Special Detachments 88 is an Indonesian forces counter-terrorism squad and a part of Indonesian Police Force. The unit is equal to America's Special Weapons and Tactics Team or SAS British Team in Britain.

9 BNPT or the National Agency for Combating Terrorism is formed as a response to the Bali Bombing in 2002. BNPT is headed by a chief who is responsible to the president. In 2012, Presidential Regulation elevated the post of BNPT chief to the Ministerial level. The main task of BNPT is to eradicate and combat terrorism. 
the growing number of religious violence ${ }^{10}$ shows that the policies on countering radicalism and terrorism needs to consider other aspects rather than a military one. Throughout this paper, I will show that there is a neglected figure within society, called modin, who has a potential to optimize the result of various de-radicalization programs, particularly those that have been initiated by the Indonesian government. In many cases, some de-radicalization programs could not be effectively implemented at the grassroot level because they tended to include only some elites from the mainstream Islamic groups in the country, who have not enough influence to the daily life of the society. Therefore, in this paper I argue that it is necessary to include modin, who has the most intense meeting with community members, in order to produce a more effective result on countering intolerant ideology throughout the country.

\section{B. Understanding the Position of Modin in Society}

In every village across the Java, particularly within the Special Province of Yogyakarta, there is a local Islamic leader who plays a significant role in leading most rituals and traditions. Several names are given to this informal Islamic leader, such as: modin, mbah kaum (lit. elderly community leader'), and rois (lit. leader). ${ }^{11}$ Although these three terms refer to the same position in most villages, in this paper I prefer to use the term modin to fit with places where I conducted this research. The term modin itself is derived from the Arabic phrase imam ad-din ('religious leader'). ${ }^{12}$ Considered as a person who leads most religious rituals and traditions conducted at a local level or dusun ('hamlet'), modin can obviously be acknowledged as the defender of traditions. Most rituals

10 Zainal Abidin Bagir et al., Laporan Tahunan Kebidupan Beragama di Indonesia (Yogyakarta: CRCS UGM, 2008); Zainal Abidin Bagir et al., Laporan Tabunan Kebidupan Beragama di Indonesia (Yogyakarta: CRCS UGM, 2009); Zainal Abidin Bagir et al., Laporan Tahunan Kebidupan Beragama di Indonesia (Yogyakarta: CRCS UGM, 2010); Zainal Abidin Bagir et al., Laporan Tahunan Kebidupan Beragama di Indonesia (Yogyakarta: CRCS UGM, 2011); Zainal Abidin Bagir et al., Laporan Tabunan Kehidupan Beragama di Indonesia, ed. by Suhadi Cholil (Yogyakarta: CRCS UGM, 2012).

11 According to Mbah Parno, a modin at Kragilan hamlet, those three terms are still used by villagers. However, the term "modin" is the most frequently used in the hamlet. Personal interview, 22 November 2015.

12 Ibid. 
and traditions, especially related to the special moments of human's life cycles, such as aqiqahan ('ritual of slaughtering goat for baby's birth'), sunatan ('ritual of circumcision'), nikahan ('wedding ceremony'), mapati ('ritual for the fourth month of pregnancy'), mitoni ('the seventh month of pregnancy'), and slamatan kematian ('rituals for commemorating the death person') are conducted and lead by the modin. Other rituals and traditions related to preserve the balance between macro and micro cosmos for the social life of community such as Bersib Desa (ritual for spiritually cleaning up the village) and commemorating special events such as Muludan (commemorating the birthday of the Prophet Muhammad), Suroan (the Islamic and/or Javanese new year), and so forth, have also been performed regularly by the modin. ${ }^{13}$ These rituals and traditions clearly indicate the significant position of modin in the everyday life of community.

Historically speaking, the position of modin was very prestigious. modin, along with other positions at a village level, such as kepala desa (the head of village), bekel (the head of village's security), kumu (the head of village's administrators), is also considered as a representation of the Sultan at a local level. In the past, especially before the New Order era, modin was appointed by Penghulu Keraton (spiritual advisor of the Sultan) and considered as the officer of Sultanate who received regular payment from the Sultan. Interestingly, similar to other position under the kingdom system, the position of modin is appointed by the Sultan and usually will be passed to his son. Therefore, the son of modin is commonly considered as the next modin. If a modin has more than one son, the oldest son will have the priority to be the next modin, or in some cases, the most pious sons will replace the position of his father. However, in this case, modin has a prerogative right to choose among his sons whom will replace his position. As a direct representation of the Sultan in conducting religious rituals and traditions at local level, the position of modin was considered prestigious. Moreover, according to Javanese cultures, most human's cycles of life, from his birth, puberty, marriage, to death have to be

${ }^{13}$ For detail information on various Javanese rituals of the life cycle, see: Muhammad Sholikhin, Ritual dan Tradisi Islam Jawa: Ritual-ritual dan tradisi-tradisi tentang kehamilan, kelabiran, pernikahan, dan kematian dalam kehidupan sehari-hari masyarakat Islam Jawa (Yogyakarta: Narasi, 2010). 
celebrated through certain rituals called slametan (lit. asking for God's blessing), in which modin have played the most significant roles. In other words, the everyday life of villagers within the kingdom system could not be separated from the modin.

During the early period of modern Indonesian state, modin continued to play a significant role in leading religious activities and traditions. However, the growing numbers of modernist Muslims organization of Muhammadiyah in Yogyakarta in the early twentieth century had gradually eroded the role of modin in society. The idea of purification of Muhammadiyah, coupled with the needs of modernized people, which tended to be more rational and pragmatic, had threatened the existence of some religious rituals and traditions, in which modin had led for years. The authority of modin, as a result, had decreased significantly especially in some urban areas of Yogyakarta where members of Muhammadiyah were concentrated. Under the New Order era, the significant role of modin in society has gradually reduced. Started with the implementation of Law of the Village Government (UU No. 4 1978), modin has no longer considered as the village officer who has right for bengkok. ${ }^{14}$ Modin under the New Order era only received a voluntary payment for people who conduct the rituals or traditions. ${ }^{15}$ Besides, a massive modernization process, which leads people to be more rational and practical, has created a reluctant among them to perform what they are seen as "unnecessary" rituals and traditions. The role of Modin has been reduced only to deal with the death body, such as cleansing, covering, and then burying. Therefore, the position of modin eventually becomes not interesting for younger generation, even for the sons of modin himself. This condition, however, is not automatically pushed modin away from contributing to shape a daily religious activity of people, especially those who live in rural areas.

Echoing to the situation of Islam worldwide in the late 1990s, various trans-national Islamic groups have appeared in Indonesia. They

14 Bengkok is a right to use the village's field-rice as a complementary for his salary or receive regular salary from the Sultanate. Most villages' positions are paid using this system.

15 This voluntary payment is known with the term "amplopan" because the money is put in a white envelope and it is given to modin before or after he leads the religious activities. 
are actively competed with more established Islamic groups, such as Muhammadiyah and Nahdlatul Ulama, to sell their ideology. Most of these relatively new organizations have brought the ideas of purification and pan-Islamism. These models of religiosity have put various local rituals and traditions, as performed by modin for centuries, into danger. They recognized those practices as un-Islamic and even parts of heresies within Islam. In this context, the position of modin has become more problematic. He is not only has to face those who reluctant to perform rituals and traditions based on economic reasons, but he also has to deal with some stigmas from activists of these puritan trans-national Islamic groups who often regard those practices as bid'ah (lit.heresy) and syirik (lit. apostasy).

\section{Various Models of Modin in Sidoluhur}

Total number of worship facilities is important in observing religious activities within rural communities. Mosque or Musholla can be seen as an indicator for various Islamic groups existed in the village, as well as to predict the degree of religious activities among different Islamic groups in the village. The dynamic religiosity of the inhabitants, including their heterogeneity in expressing their religious beliefs, is very important to be noted to add an alternative way in dealing with the growing number of religious intolerant in the country. The mixed model of practicing religious activities is a common phenomenon for the villagers in Sidoluhur. The practice of tablilan, for example, is not only followed by traditional Muslims, but it is also attended by all people based on what they called lingkungan kenduren (lit. 'communal feast groups'), which consists of 40 to 50 families, depending on the size of Rukun Tetangga (RT) or Rukun Warga (RW) ${ }^{16}$, regardless their religions or religious affiliations. Although this model of religiosity is not a new phenomenon, as shown in a popular term of Munu ('Muhammadiyah-

16 Rukun Tetangga (RT) is the smallest administrative institution within society. It consists of 20 to 35 families depend on the density of certain areas. Meanwhile, Rukun Warga (RW) is an administrative institution which consists of some RT, ranging from 5 to $10 \mathrm{RW}$, depending on the size of each RT. 
Nahdlatul Ulama') and Marmud ('Marhaenis-Muhammadiyah') ${ }^{17}$ based on a research on Muhammadiyah members conducted by Mulkhan, ${ }^{18}$ it can be used as an indicator of the creativity among the villagers in solving the problem of differences, or sometimes even opposite way in understanding religious doctrines.

According to Kaur Kesra (the head of Social Welfare Affairs) ${ }^{19}$ at Sidoluhur, although there are only two Islamic organizations acknowledged in the village office, Muhammadiyah ${ }^{20}$ and Nahdlatul Ulama ${ }^{21}$, there are actually some other Islamic organizations, such as Abangan groups, ${ }^{22}$

17 Marhaenism is a term coined by Soekarno in 1927 to be used in similar meaning with the term "proletar." This ideology consists of three aspects: class analysis, socio-nationalism, and socio-democracy. Soerojo (1988) stated that the term Marhaen stands for Marx-Hegel-Engels. This ideology was used as the foundation of Partai Nasional Indonesia, the winner of the first general election in 1955. In its later development, people simply identified this ideology as nationalist.

18 Abdul Munir Mulkhan, “Gerakan 'Pemurnian Islam' di Pedesaan: Kasus Muhammadiyah Kecamatan Wuluhan, Jember, Jawa Timur”, Ph.D. Dissertation (Yogyakarta: Universitas Gadjah Mada, 1999).

19 Kaur Kesra (the head of Social Welfare Affairs) is a unit under the coordination of the head of village. This unit has tasks to ensure the social and religious life of all people in the village, including to coordinate all modin across the village.

20 Muhammadiyah is the second largest Islamic organization in the country. It was founded by K.H. Achmad Dachlan in 1912 in the city Yogyakarta as a reformist socio- religious movement, emphasizing on ijtihad - individual interpretation of the Qur'an and the Hadith as opposed to the concept of taqlid or following ulama, which is commonly practiced by traditionalist Muslims. Within the Indonesian Islam discourses, Muhammadiyah is widely known as a representation of modern muslim organization.

21 Nahdlatul Ulama, or known as NU, was formed by K.H. Hasyim Asy'ari in 1926 as a reaction toward the raised of modernist movements in Indonesia and other Muslim world, which questioned various local Islam practices and considered them as forms of heresy within Islam. Therefore, NU is commonly associated with traditional Muslims in Indonesia, especially in Java. Nowadays, the NU is considered as the biggest Islamic organization in the country with estimated members and sympathizers more than 55 million people.

22 The term "Abangan" is also known as "Kejawen" is considered as a stream of the six acknowledged religions according to the government and placed under the control of the Ministry of Education and Culture. The teachings of Abangan are derived from combining the teachings of a certain religion, particularly Islam or Christianity and local (Javanese) beliefs and values, with an emphasis on substantive teachings rather than formal aspects, such as conducting five day prayer, fasting, and so forth. In its 
Lembaga Dakwah Islam Indonesia (LDII) ${ }^{23}$ and more recently, some Salafi groups. ${ }^{24}$ Although there is no official data stating the total members of these Islamic groups because the government census is only related to six acknowledged religions, the estimated numbers of these groups, based on the estimation from the village officer, Muhammadiyah is followed by 47 percent of people in Sidoluhur, NU is 32 percent, Abangan is 13 percent, while the rest, including LDII and Salafi is around 8 percent of members and sympathizers ${ }^{25}$ in the village. ${ }^{26}$ The domination of Muhammadiyah in this village can clearly be seen from some decisions made by the village government related to the issue of religious holidays, especially the Idul Fitri. ${ }^{27}$ In addition, Mbah Muh, one of the oldest modin in Sidoluhur told me the special characteristics of Sidoluhur compare to other villages:

"Sidoluhur is so special; you can find any models of people, in term of their beliefs. We have plenty of those who involved with Communist Party. Most of them now converted to Catholicism or remain as genuine Abangan. We also have Muhammadiyah ndeles and NU totok (lit. very

simplest form, Abangan is also known as nominal Muslims.

23 Lembaga Dakwah Islam Indonesia (LDII) is formed in January $3^{\text {rd }} 1972$ with the name of Yayasan Karyawan Islam (Muslim Employee Foundation), known as YAKARI. In 1981, it was renamed to Institute of Islamic Employees/Lembaga Karyawan Islam (LEMKARI). Based on the decision made during the fourth LEMKARI council in 1990, the name of this organization was changed into Lembaga Dakwah Islam Indonesia (Indonesian Institute of Islamic Dakwah). According to the Ministry of Religious Affairs, this organization is categorized as puritanical Islam. As other puritanical groups, this organization is claimed to base their dakwah solely to the Qur'an and the Hadith and tend to reject all religious practices that presume as having no guidance from the Prophet Muhammad.

24 Interview with Subawa, 19 November 2015.

25 The term sympathizer is used here to emphasize that none of these Islamic groups have strict rules and offer membership card for their members. Therefore, it is nearly impossible to have exact data on total member of each Islamic groups. Besides, asking religious affiliation for Javanese people is considered impolite, like asking age to women in Western culture.

26 Interview with Subawa, 27 November 2015.

27 On deciding the exact day of celebrating Idul Fitri, Muhammadiyah and Nahdlatul Ulama has their own methods, hisab (calculation) and rukyat (moonsighting) respectively, which often creates differences. In this case, the Sidoluhur government always follow the decision of Muhammadiyah, even if the central government through the Ministry of Religious Affairs decided to follow Nahdlatul Ulama version. 
fanatics to Muhammadiyah and NU), and other strength groups such as LDII (Lembaga Dakwah Islam Indonesia), which is known for their attitude to clean on a place in their mosque that was used by someone from outside their groups. So, it is very complex situation but we never have a serious conflict on these issues". ${ }^{28}$

Based on this fact, it is clear that Sidoluhur is a perfect place to observe the social and religious dynamics of modin in the midst of rapid social changes. How far modin could play a significant role in coloring Islamic practices within the diversity of Islamic groups in society becomes an important question to be answered to determine whether or not he will be able to give a contribution in erasing or softening intolerant ideology at the grassroots level.

In Sidoluhur, there are 28 modin who serve for 15 kring or padukuhan (lit. hamlet). Based on statistical data provided at the village's office, total population of Sidoluhur is 10,457, which consists of 5,132 men and 5,325 women. Sidoluhur is also divided into $77 \mathrm{RT}$ and $35 \mathrm{RW}$. If one RT consists of 40 families, one modin has to serve around 110 families. The job of modin is not easy. In many cases, modin has to be ready for 24 hours to give service to community. For example, when someone dies at $10 \mathrm{pm}$, modin has to taking care of his body according to Islamic teachings, which includes cleansing, covering, and burying, and stay the whole night in the house of the death person until the burial ceremony, which mostly conducted at $2 \mathrm{pm}$ the next day. ${ }^{29}$ Moreover, the job for modin does not end on the burial day, but usually will continue to lead

28 Original quotation from Mbah Muh as follow: "Sidolubur meniko benten kalian desa lintunipun. Wonten Sidolubur mriki aliran nopo kemawon wonten. Wonten ingkang rumiyin nderek Partai Komunis. Sakmeniko katha ingkang mlebet Katulik menopo tasib nderek kelompok abangan. Ten mriki nggih wonten sing Muhammadiyah ndeles kalian NU totok. Wonten malih kelompok ingkang radi aneh kados LDII ingkang gadahi kebiasaan ngguyang masjidipun menawi didamel sholat kalian tiyang ingkang mboten sealiran. Dados saestu kathah sanget ingkang benten, tapi nggih mboten nate tawuran kok". Interview with Mbah Muh, 23 September 2015.

29 In most cases, the ceremony of funeral is actually started at $1.30 \mathrm{pm}$ and will last around $14.15 \mathrm{pm}$. Most people, usually farmers, have their lunch time first, doing Dhubur prayer, and preparing to attend the funeral ceremony. Besides, another reason why most funeral is conducted at $2 \mathrm{pm}$, according to Mbah Parno, is to avoid a very hot weather if it is conducted right after Dhubur prayer. 
yasinan and tablilan ${ }^{30}$ for consecutive three or seven nights, depending on the request of the death's family. ${ }^{31}$ For these kinds of services, usually modin will receive small amount of money from the family as his payment.

In the past, modin is lent a field-rice to be used as his payment called bengkok. However, since the needs to modernize village, the central government have introduced several new regulations to revitalize the village government. One of these new regulation is related to the position of modin. The rationalization of the village government body had pushed out modin from the structure. Modin is no longer considered as an autonomous unit within the village government body but it is placed under the unit of social welfare. As a result, modin has no longer right to have bengkok from the village government (Interview with Suparno, 23 August 2015). After having no bengkok, all modin in Sidoluhur only received a small amount of money as monthly payment from the government regency through the village office. Each modin receives around 300,000 rupiah, which is far from the standard of minimum wage for the region. ${ }^{32}$ Some modin, especially those who still below 55 years old, are prefer to have bengkok than receive this small incentive from the government.

This imbalanced compensation for modin has created a reluctant for the younger generation to prepare for being the next modin, even for the sons of modin that actually have a right to replace the position of his father. The problem of regeneration resulted on the higher average age for modin, compare to other village's officers. Muhadi, for example, has served as modin since 1968. In his 84 years old, he still has to lead most religious activities in his hamlet. His son, however, has been appointed to be modin in different hamlet in 2001 because there was no one in that hamlet willing to take the position as modin after the previous modin died in 1999. From 28 modin in Sidoluhur only two modin who are still under

30 Yasinan is reading Surah Yaasin, the $93^{\text {rd }}$ surah of the Qur'an, while tablilan is chanting certain formulas of dzikir (remembrance of God) which is designated to ask Allah for forgiveness especially for the dead person. Both recitations are approximately done within one and a half hour.

31 In the past, Yasinan and Tablilan is conducted every night after the funeral for seven days.

32 Using the current currency, 300,000 rupiah is equal with US\$30. The standard of minimum wage for this region is 1,050,000 rupiah. 
forty years old. Most modin in Sidoluhur are above 55 years old. ${ }^{33}$

Although there is only a little appreciation in term of material income, the position of modin is still considered prestigious, especially for villagers. The important position of modin in leading most religious activities of villagers shows how modin is acknowledged and respected by all villagers. Having a high social status in rural areas is very important, especially if someone wants to obtain power or to win an election for certain positions in society. In this case, the position of modin is considered influential in gaining supports from the grassroots level. In fact, many modin are being used by the head village candidates to be an important part of their campaigners. This situation clearly shows that the position of modin, especially in Sidoluhur, is still considered important, not only in regard with his main tasks to serve people in religious rituals, but it also influential in gaining trust at the grassroots level.

Interestingly, although there is a problem on regeneration, the contestation among Islamic groups to fill the position of modin is apparent. From 28 modin in Sidoluhur, there are 7 modin who come from the Nahdlatul Ulama, 2 modin are associated with Muhammadiyah, and the rest of them are considered as abangan. These three models of modin, based on their religious affiliation, have implication on the way they lead the community in practising rituals or traditions. In many cases, modin with abangan and Nahdlatul Ulama backgrounds share many similarities compared to modin with Muhammadiyah background.

The first model of modin can be called as "abangan modin". There are some characteristics of abangan modin compare to other models of modin. In general, Abangan modin uses mostly Javanese language in leading the rituals. They prefer using Javanese translation to Arabic language, except for reciting the Qur'an and some dzikir formulas. Most rituals and traditions conducted by Abangan modin are simpler and usually performed after the maghrib prayer, around $6.30 \mathrm{pm}$. However, if there is a special request from the host regarding what should be read during the ritual, modin has to adapt to such request. Most abangan modin in Sidoluhur does not have a formal religious education. ${ }^{34}$ They usually attain knowledge to lead rituals or traditions from their parents or it is only based on what

33 Interview with Suparno, 23 November 2015.

34 Interview with Mbah Muh, 3 October 2015. 
they usually have been done by previous modin. There is no guidance book available for conducting rituals and tradition. All materials needed for performing rituals should entirely be learnt by heart.

The second model of modin in Sidoluhur is NU modin. Similar to abangan modin, their main job is to take care of the death body, from cleansing to the funeral. However, compared to abangan modin, all NU modin in Sidoluhur graduated from various pesantren ${ }^{35}$ across the Java, mostly from pesantren in East Java. In leading rituals and traditions, they use more Arabic language than the Javanese because they use a small book entitled Majmu' al-Syarif (the compilation of some Surah in the Qur'an with some drikr formulas). ${ }^{36} \mathrm{NU}$ modin prefers to start their activities after performing Isya' prayer or at $8 \mathrm{pm}$. They argued that there is no enough time between 'maghrib and 'isyak, to perform yasinan and tablilan. Therefore, for them, it is better to postpone the rituals or traditions to give chance for people to perform Isyak prayer in time.

The third model is called Muhammadiyah modin. Most Muhammadiyah modin, especially in Sidoluhur are the former religious teacher at Muhammadiyah elementary or secondary school or still actively involved in Muhammadiyah boards at local level. Unlike Abangan and NU modin, Muhammadiyah modin limits their activities to deal only with taking care of the death body up to the burial process. They do not willing to lead yasinan or tablilan for the death because they believe that those practices are considered heresy. However, they will not say anything to those who still practice those rituals and traditions. One of Muhammadiyah modin in Sidoluhur, Mr. Arwakun, has different way to show his rejection to those practices. He usually come to the ceremony because of the invitation from the death's family, but when the ceremony is started, he only asks the audience to pray for the death person without reciting Surab Yaasin or other dzikr formulas. ${ }^{37}$ Interestingly, the members of community in which their modin is Muhammadiyah member, they usually form a group

35 Traditional Islamic educational institution, which only teach Islamic knowledge and memorize the Qur'an.

36 Most Muhammadiyah followers believe that all surah in the Qur'an have the same position. Therefore, they reject the idea of special surah as compiled in Majmu' asy-Syarif. Besides, the idea of sending the rewards (pahala) for reciting this special book to the dead people is unknown within the doctrines of Muhammadiyah.

37 Interview with Mbah Arwakun, 25 August 2015. 
of yasinan and tablilan led by someone among them who has the adequate knowledge to lead the rituals. Therefore, if there is a member of the death person wants to have yasinan and tablilan, they usually invite these two groups, modin Muhammadiyah and the group of yasinan and tablilan.

Although each modin already has his own area of operation, based on RT or RW, but in practice, it is still possible for the host to invite modin from other areas, especially when the invited modin is more senior or has different religious affiliation with modin in that area. This flexibility indicates that there is a notion of toleration among modins and the villagers. However, since leading a religious rituals, such as tablilan and yasinan, can be seen as one of potential income for modin, there is an unwritten rule for those who prefer to invite modin from different area to provide two envelopes, one for the invited modin and another for the local modin. Even if the local modin did not attend the rituals, the host is still have an obligation to send the envelope and berkat ${ }^{38}$ to him. This unwritten rule is aimed to avoid clash and maintain the harmonious interraction among modin in the village, as described by Sulastri, who practiced this model for a long time:

"My house is actually under the area of Mbah Parno (modin in Kragilan hamlet), but because the house of Mbah Muh (modin of the next hamlet) is closer than Mbah Parno, I invited both whenever I have some rituals to do. Usually I provide two envelopes for both and I let Mbah Muh to lead the ritual because he is older than Mbah Parno". 39

It is clear that maintaining the relationship among modin is also become a concern of all villagers. For most people in Sidoluhur, the issue of seniority is considered an important aspect in order to avoid potential conflict among modin. Although younger modin usually has better knowledge of Islam, he will not be asked to lead the ritual if there is an older modin, except the later asks to do so. This attitude reflects a general worldview of Javanese, who prefer to prioritize social than private or individual life. ${ }^{40}$ However, these relatively harmonious relationships

${ }^{38}$ Berkat is a basket of foods which is usually given to all participants of the rituals to take it home.

39 Interview with Sulastri, 4 December 2015.

40 Franz Magnis-Suseno and S. Reksosusilo, Etika Jawa dalam Tantangan: Sebuah Bunga Rampai (Yogyakarta: Yayasan Kanisius, 1983); Suwardi Endraswara, Etika Hidup 
among modin in Sidoluhur does not automatically mean the absent of tensions, especially since the appearance of Salafi activists in the region in 2004. Some modin, especially those who affiliated with Muhammadiyah, feels more comfortable to express their rejection to the practices of most rituals, including yasinan and tablilan, as Salafi activists started to label those as heresies of Islam.

\section{Challenges from Salafi Groups}

Similar to other places across the country, the presence of Salafi groups often creates a new tension in society. ${ }^{41}$ The characteristics of puritanical movements combine with apolitical nature of Salafism, have created a non-compromising attitude to differences. Literal interpretation of Islamic doctrines, have left no room for accommodating local values and traditions. Any rituals and traditions that have no guidance from the Prophet Muhammad are considered as heresy and even idolatry. These intolerant doctrines are strongly followed by the Salafi activists. This narrow understanding of Islamic doctrines put most Salafi activists in opposite directions toward the majority of villagers, especially those affiliated with the abangan and NU.

The appearance of Salafi groups in Sidoluhur began in 2004 with the establishment of a new mosque in the hamlet of Tebon, which replaced the former mosque, to accommodate more Muslims for Friday prayer. This new mosque was totally funded by a Salafi group, which also wanted to use the upper story of the new mosque as a pesantren. ${ }^{42}$ After the building process finished in 2005, there were two organizational bodies within the mosque: takmir masjid (the board of the mosque), which consists of the same board member as in the old mosque and Yayasan al-Madinah (al-Madinah Foundation), which runs a pesantren for memorizing the Qur'an and conducting some short trainings on Islamic studies, particularly to prepare someone to be a da'i (preacher). The

Orang Jawa: Pedoman Beritiket dalam Menjalani Kehidupan Sehari-hari (Yogyakarta: Narasi, 2010).

41 Noorhaidi Hasan, Laskar Jihad: Islam, Militancy, and the Quest for Identity in Post-New Order Indonesia (Ithaca, N.Y: Cornell University Pres, 2006); Jamhari and Jajang Jahroni, Gerakan Salafi Radikal di Indonesia (Jakarta: Raja Grafindo Persada, 2004).

42 Interview with Ramelan, 12 October 2015. 
activists of al-Madinah Foundation are members of Wahdah Islamiyah, a Salafi group based in Makassar and has several branches across the country. ${ }^{43}$

The new mosque, which is located only 20 meters from the older one and both use the same name: al-Iman is an interesting phenomenon. The former building of al-Iman mosque has become a musholla. This creates a unique situation: a mosque and a musholla with the same name, only separated by a small road, offering similar religious services, except for Jum'ah prayer, which according to Islamic teaching has to be conducted in a mosque. In this case, the notion of competition is so apparent. Some differences in performing daily prayer between these two worship places can easily be identified, for example: reciting qunut ${ }^{44}$ in the morning prayer (lit. subuh prayer), distinguishing a way of sitting in the prayer ${ }^{45}$, and so forth.

Besides, the presence of some ustadr, (teachers) of pesantren, who rent several houses around the mosque, have become new competitors for modin in providing religious explanations to answer certain questions from the people around the mosque. In this case, the capacity of most modin in mastering Islamic knowledge is incomparable to some ustad\%: Many modin in Sidoluhur, as described, come from abangan background,

43 Noorhaidi Hasan, "The Salafi Madrasas of Indonesia", in The Madrasa in Asia: Political Activism and Transnational Linkages, ed. by Farish A. Noor, Yōgīndar Sikkand, and Martin van Bruinessen (Amsterdam: Amsterdam University Press, 2008); Agus Moh Najib and Yudian Wahyudi (eds.), Gerakan Wahabi di Indonesia: Dialog dan Kritik, Cet. 1 edition (Yogyakarta: Bina Harfa, 2009); Syarifuddin Jurdi, Sejarah Wabdah Islamiyah: Sebuah Geliat Ormas Islam di Era Transisi (Yogyakarta: Kreasi Wacana, 2007).

44 Qunut is special dua which is strongly recommended to be read in the Morning Prayer according to Syafi'i School, while other schools claimed no need to read qunut in the Morning Prayer. In this case, the musholla practicing qunut, while the mosque is not reciting it. This is actually a classical dispute between Muhammadiyah and Nahdlatul Ulama. The presence of Salafi activists have made this tensions becomes sharper because they labelled those who reciting qunut in the Morning Prayer as practicing heresy in Islam.

45 In the last sitting during the prayer (tasyahud akbir), Indonesian Muslims, both Muhammadiyah and Nahdlatul Ulama, used to sit on the floor instead of sitting on the left foot as they did for the first sitting (tasyahud awal). This last sitting is known as tawaruk. All Salafi activists in al-Iman mosque, they do not differentiate between the first sitting and the last one. This small difference has made uncomfortable for most Muslims in the village because it is different with what they know and practice for a long time (interview with Pak Mitro, 30 October 2015). 
which have little or even no knowledge in reading Arabic, while many ustadz of the pesantren graduated from some universities in Saudi Arabia. Moreover, the status of modin as an inherited job, to some extent, has created a difficulty to ensure the integrity of the future modin, as Weber noted when he explained about leadership within the categorization of traditional authority. ${ }^{46}$

The puritanical ideas of some Salafi groups, including Yayasan alMadinah in Sidoluhur, supported by the integrity of their activists, their pesantren network, and more importantly financial supports from some donors in the Middle East countries, has put modin and other defenders of rituals and traditions in bitter situation compare to what they had been done in responding the similar issue raised by some modernist and puritanical groups. In addition, challenges that have been raised by some Salafi groups are also harder compared to some Dakwah or Tarbiyah activists, which is more political as represented by Partai Keadilan Sejahtera, shortened to $\mathrm{PKS}{ }^{47}$ As a political group, Salafi activists usually do not need many considerations to give label or create stigma of certain rituals and traditions as heresy or idolatry. In this case, the consistency of Salafi groups in erasing local elements from the doctrines of Islam have become a threat for the position of modin as well as the continuity of rituals and traditions within society.

An example of this case is told by one of villagers who regularly attend Friday prayer in the mosque:

"In a Friday sermons, the khatib (speaker) asked not to practice reading various kinds of shalawat anymore, it is enough only to read "Allabumma sholli ala Mubammad". Meanwhile, other shalawat, including Nariyahan or Barzanji were considered haram (forbidden) and those who practice them can be a kafr (apostasy). At that time, I wanted to go out of the mosque to find other mosque, but I did not do it. I was really angry listening to

${ }^{46}$ Max Weber, Economy and Society: An Outline of Interpretive Sociology, ed. by Guenther Roth and Claus Wittich, trans. by Ephraim Fischoff (New York: Bedminster Press, 1968); Max Weber, On Charisma and Institution Building: Selected Papers, ed. by S.N. Eisenstadt (Chicago: University of Chicago Press, 1968).

47 Yon Machmudi, Islamising Indonesia: The Rise of Jemaab Tarbiyah and the Prosperous Justice Party (PKS) (Canberra: ANU E Press, 2008). 
that sermon". 48

From the above interview, there are two popular rituals or traditions within society that have been criticized: reciting Nariyahan and Barjanzi (stories on the biography of the Prophet Muhammad). Within traditional Muslims community, these shalawat are usually practiced every Thursday night in mosques or mushala. There are more similar statements from other villagers that have been made by some ustadz of Pesantren al-Madinah through various occasions to target other rituals and traditions within society.

For villagers, expressing a disagreement toward certain religious rituals and traditions that are practiced by other Islamic groups is not a new phenomenon. As described, people of Sidoluhur are used to deal with differences in understanding Islamic doctrines. The establishment of the Nahdlatul Ulama in 1926 is designated to protect traditional Muslims practices that had been challenged by some modernist Muslims. However, some statements that have been made by some Salafi activists are not only expressing their disagreements, but they also giving labels to others as practicing heresy and idolatry or apostasy. ${ }^{49}$ For most Muslims,

${ }^{48}$ Interview with Suratidjo, 22 November 2015. The original quotation of this interview: "Dulu pernah mas, pada saat khutbah Jum'at, khatib memerintabkan untuk tidak lagi melaksanakan bacaan shalawat yang macam-macam, cukup membaca "Allabumma sholli ala Muhammad." Sementara shalawat-shalawat lainnya, termasuk nariyahan maupun barzanji dianggap haram dan pelakunya bisa saja menjadi kafir. Saat itu sebenarnya saya ingin keluar dari masjid dan bermaksud untuk. mencari masjid yang lain, tapi ndak jadi. Wah, pokoknya benar-benar merah telinga saya mendengar khutbah saat itu".

49 This labeling phenomenon is widely known among the mainstream Muslims across the country as a takfiri ideology. Mas'ud Izzul Mujahid, Vonis Kafir: Antara Berlebihlebihan \& Ketidaktegasan, 1st edition (Solo: Jazera, 2010); Ahmad Muntaha A. M et al., Menjawab Vonis Bid'ab: Kajian Pesantren, Tradisi \& Adat Masyarakat, 1st edition (Kediri: Pustaka Gerbang Lama, 2010).Takfiri means a Muslim who accuses another Muslim (or adherent of another Abrahamic faith) of apostasy. The accusation itself is called takfir, derived from the word kafir (unbeliever). It is believed that this takfiri ideology is the most susceptible factors that lead someone to radicalism and terrorism. Most hardliner of Islamic groups worldwide, such as: al-Qaedah, Jamaah Islamiyah, and ISIS are the followers of this ideology. For them, there is only one truth, which of course, only belongs to them. Everything which is different with them is considered false and misguided. This way of thinking, supported by a literal interpretation of the doctrine of "amr al-ma'ruf wa nabi al-munkar" or obligation to do good deeds and prevent bad deeds, has created spirit to blame others. Therefore, the problems of intolerant and 
these labels are considered as serious offence because if someone is being accused as practicing apostasy or becoming kafir (unbeliever), he can get severe punishment, being killed. In Islam, labeling other fellow Muslims as unbeliever without adequate evidence is a serious sin because it involves the most fundamental factors in Islam, aqidab (faith). Not only within Islamic teachings, but also in all other religious doctrines, apostasy is considered as the biggest sin of humans in front of their God.

Salafi groups in Sidoluhur also have similar way of thinking. The jargon of "return to the Qur'an and the Hadith", as in other purification groups, is always come up in their daily conversation with the villagers during the pengajian. The most popular hadith, "kullu bid'ah al-dhalalah, wa kullu dhalalah fi an-nar" (every innovation is misguided, and every misguided things is in hellfire) have become the main weapon for Salafi activists to oppose any rituals and traditions across the Java that were actually created and modified by Walisongo (lit. the nine saints), who had succeeded in spreading Islam across the Java. Salafi activists in Sidoluhur had systematically created a negative opinion about Walisongo in order to have a justification for claiming that rituals and traditions practices are wrong and misguided. Various statements on this case are told by their ustad to the villagers through some religious activities and a free pamphlet distributed on the Friday prayers. Wasith, a villager who regularly practices yasinan and tablilan told me, "I read from the pamphlet stated that the dakwah of Walisongo is not done yet. Walisongo actually wanted to abolish rituals and traditions but they do it step by step such as in the prohibition of khamr (alcohol) case". ${ }^{50}$ During the regular pengajian (study of Islam), in every Thursday night, a Salafi ustadz also bluntly said: "if we want to respect Walisongo, we have to continue their dakwah to remind Muslims to leave tablilan, yasinan, nariyahan, and other un-Islamic practices. Those practices are derived from Hindu's teachings not from Islam". ${ }^{51}$ It seems that Salafi activists also use one of theories on the coming of Islam in

radicalization are deeply rooted in a narrow understanding of Islamic doctrines, which cannot be solved only with a military approach Turmudi and Sihbudi (eds.), Islam dan Radikalisme di Indonesia; Effendy and Hadi (eds.), Agama dan Radikalisme di Indonesia.

50 Interview with Wasith, 21 November 2015.

51 Fieldnote, 24 September 2015. 
the Archipelago, as proposed by de Jong, ${ }^{52}$ claiming that Walisongo are only legends because there is no adequate written document supported the story of Walisongo.

The rejection of rituals and traditions that have been acknowledged for centuries as local Islamic practices, as it is clearly shown by Salafi activists in Sidoluhur, to some extent, have created confusion among the villagers. Moreover, most of them have no adequate knowledge of Islam. As in other regions, lay people are often considered as practicing Muslims. In many cases, they even do not need to have any reasons to do certain religious rituals. Their understanding of Islam is merely based on examples provided by their parents and ancestors. Therefore, when they see something different with what they have done in a daily basis, they will easily get confused. In other words, when the villagers are repeatedly informed about different understanding of Islamic teachings, especially if the speakers are considered masters in Islam or Arabic, they will easily follow that understanding. This happens to some villagers who started not to attend yasinan and tablilan anymore.

\section{E. Reinterpreting Traditions and Rejecting Intolerant Ideologies}

Salafi's stigma on local Islamic practices as heresy of Islam is not the only challenge that have to be faced by modin and all of his supporters. Modernization and globalization also have a contribution in marginalizing the position of local Islamic traditions in society. Many people, especially in urban areas, are reluctant to perform some local Islamic practices, such as yasinan and tablilan, are usually based on pragmatic and economic reasons. Modernization and globalization have changed the way people practice their religiosity. Symbolic meanings for practicing local Islamic traditions become less important for modern people. However, some adjustments have actually been done related to those local Islamic practices. The length of conducting tablilan, for example, has been

52 Azyumardi Azra, The Origins of Islamic Reformism in Southeast Asia: Networks of Malay-Indonesian and Middle Eastern "Ulama" in the Seventeenth and Eighteenth Centuries (Crows Nest, NSW: Asian Studies Association of Australia in association with Allen \& Unwin and University of Hawaii Press, 2004); A. Hasymy, Sejarah Masuk dan Berkembangnya Islam di Indonesia: Kumpulan Prasaran pada Seminar di Aceh (Medan: Alma’arif, 1981). 
modified from seven days to only three days. In the case of berkat $t^{53}$ also has been changed. In the past, berkat has to be matengan, which consists of rice, fried chicken, beans, vegetables, and so forth. But now, berkat is commonly changed to buns of bread. These adjustments have created a new version of tablilan which is better suit for modern people. However, criticism toward various local Islamic traditions, as it is raised by the Salafi activists, seems hard to overcome using a theological debate. This model is nearly impossible to implement since both sides, modin and Salafi activists, have their own ways in interpreting and understanding certain Islamic doctrines. In this case, an example provided by Mbah Muh is interesting to be noted:

"It is useless to have theological debate with Salafi activists because they only believe in their own interpretation. It is the nature of most teachings that can be interpreted in many ways. All Muslims, regardless their religious affiliations, want to ittiba' (to follow) the Prophet Muhammad. In term of using clothes, for example, Salafi activists tend to use literal interpretation, which means we have to use the same clothes with Rasulullah, using Arabic clothes with turban. However, it is also understandable if we have another interpretation like this: because Rasulullah is Arab, he used Arabic clothes as other Arabs did, regardless they are Muslims or non-Muslims. So, if we want to follow Rasulullah, as a Javanese, we should use Javanese clothes, as other Java people do". ${ }^{54}$

There are always various kinds of interpretations. One verses or a hadith can be used by both sides as theological basis for reaching different goals.

In this case, reinterpreting the meanings of certain local Islamic practices can be a good tool in defending traditions. The goal of providing more contextual meanings for traditions is not only to defeat the Salafi activists, but also to build awareness among the villagers upon the importance of those local Islamic practices for maintaining more harmonious social interactions among the members of the hamlet. The ability of most Muslims, especially the young generations, to understand meanings of performing rituals and traditions is decreasing for time to

53 Berkat is a basket of foods which is distributed to all participants of tablilan at the end of the ritual.

54 Interview with Mbah Muh, 27 November 2015. 
time. One of the main characteristics of Javanese is a massive use of symbols in everyday expressions, including in a religious one. ${ }^{55}$ Many local Islamic traditions that were formed by the Walisongo, use symbols to represent various expressions from those who practice the rituals. Almost every recitations, body movements, and even different kind of foods that are served in the rituals, has different meanings. Mbah Muh, for example, has said:

"Wonten salah setunggaling ajaran saking kanjeng Sunan Kalijaga, menawi tuan rumah slametan meniko paring daharan dipun perintah ngedalaken tigo wijikan ingkang dipun sukani tigang macem kembang: mawar, kenongo lan kanthil. Wijikan meniko dados perlambang yen uripe menungso niku mawarno-warno, kulo-panjenengan keno ngone keno ngene, namung ati kito kedah kantbil marang Kang Kuoso". 56

There is a teaching from Sunan Kalijaga [one of the Walisongo members] to provide three wijikan (water in small bowl to wash the hand before and after eating) filled with three different flowers: roses, kenanga, and kanthil. These three different flowers become symbols to remind us that human life is so colorful; we can choose our styles of life whatever we wants, but we have to put God in our hearts.

This example shows us the complexity of Javanese people in using symbols to represent their expressions and to remind us to God. All parts of rituals have an important meaning, even only for wijikan (hand washing-bowl), as described above, reminds us to always give a room in our hearts for God. Every item, including food that is used in most rituals also has its own meaning. A food, similar to pancake, called "apem", for instance, is always served in every yasinan and tablilan. The word "apem" is derived from the Arabic word "afwun" means "asking for forgiveness". So, by serving apem to all guests, the host wants all invited audiences to give their forgiveness to his relatives, who passed away.

Unfortunately, many people in Sidoluhur, especially the youths, have no more understanding on various symbols used in rituals and traditions. They do not interesting to learn about various symbols.

55 Ibtihadj Musyarof, Islam Jawa (Yogyakarta: Tugu, 2006); M. Bambang Pranowo, Memahami Islam Jawa (Tangerang: Pustaka Alvabet \& Indonesian Institute for Society Empowerment / INSEP, 2009).

56 Interview, 23 November 2015. 
Modernity and rationality have forced them only to think pragmatically. Most of them are still practice those rituals and traditions but without any purposes except for following the traditions from their parents. They even change some items on certain rituals, with something more practical, without considering the meaning of symbols that has been eliminated. ${ }^{57}$ Ironically, some modin also have no better knowledge than the youth in explaining various symbols used on rituals. Only elderly modin, mostly from Abangan, who are still consistently give explanations on various foods that are served by the host. Therefore, there should be a guidance book explaining every detail on rituals and traditions, including an effort to reinterpret meanings to adapt with the current situation.

Restoring symbols and their meanings on certain rituals and traditions is essential. The ignorance of these symbols and meanings leads people to easily judge local Islamic practices as useless and even misguided. The complicated preparation for providing various traditional foods in yasinan and tablilan, for example, is commonly seen as wasting time and money. Many Muslims do not see that this complicated preparation actually becomes means for community to maintain their social relationship with others. There is a tradition among Javanese called rewang or helping the host to make any preparation for conducting rituals. In rewang, neighbors, especially women, will come to the host in the morning and bring with them any necessary tools to prepare for various foods..$^{58}$ During the preparation, there are plenty of times for them to socialize and discuss their everyday life. However, it seems that the spirit of rewang will gradually be eliminated. Many people prefer to choose foods based on their practicality. They can just make a call to order some modern cakes or fast foods to be served for their invited guests. This practical way of thinking, as a consequence of the spread of modernity and rationality in society, has a serious threat for rituals and traditions, as well as the social life of community in general.

The role of modin in reinterpreting the meaning of local Islamic practices will help us to preserve and maintain rituals and traditions, which eventually lead to strengthen national identity. At least, it can build awareness among the youth generation in facing various groups,

57 Interview with Ramelan 24 August 2015.

58 Endraswara, Etika Hidup Orang Jawa. pp. 27-31. 
including Salafi. The idea of pan-Islamism, as it is brought by most transnational Islamic groups, including the Salafi, is totally moved into opposite direction compare to the spirits of Islam that have been introduced by Walisongo hundreds years ago. Moderate and accommodative characteristics of Indonesian Islam are seriously being threatened by those intolerant ideologies and narrow understanding of Islam. It is our responsibility to show that Indonesian Islam can be a role model for the rest of Muslim worlds. To preserve this goal, modin can give a significant contribution by acting as the defender of traditions in his community.

\section{F. Concluding Remarks}

The involvement of modin in filtering intolerant and radical understanding of Islamic doctrines, as proposed by most transnational Islamic groups, especially the Salafi, is based on the fact that most of those groups have put local Islamic practices as a target for their dakwah. It is nearly impossible to realize the idea of pan-Islamism without eliminating local wisdoms. Literal interpretation of Islamic doctrines, coupled with the spirit of purification has created no room for differences. The use of some terms, such as bid'ah (heresy) and syirk or kufr (idolatry or apostasy) to label most local Islamic traditions, such as yasinan, tablilan, mapati, mitoni, and so forth, to some extent, shows an intolerant ideology of the Salafi that may lead to an intolerant attitude and violence. As the defender of traditions at grassroots level, it is necessary to include modin on various programs for countering an intolerant ideology.

There are some advantages to involve modin in this case: first, modin has a special social position in his community; second, modin is the most intense person in leading community meeting at the lowest level; third, the position modin is directly impacted by the appearance of the Salafi groups; and fourth, modin has a better knowledge on the dynamics of his community. These advantages will help the government to take a more appropriate policy in countering an intolerant ideology based on the real situation, which may differs from one community to another. As a result, the policy has a greater chance to be implemented effectively in society.

The role of modin in reinterpreting the meanings of conducting various local Islamic traditions is essential, especially for guarding Muslims of the hamlet from intolerant ideology, not only for defeating 
the Salafi activists, but also for creating awareness among villagers on the importance of those traditions. Most members of the community, especially the youth, do not really understand the use of symbols in every rituals and traditions. This ignorance will easily lead them to judge the rituals and traditions as unimportant and waste their money. Moreover, this attitude will also prone to be influenced by intolerant ideology to oppose the existences of local Islamic practices. By doing these two efforts, we can revitalize the role of modin in society, preserving local Islamic identities, and eventually hope that he can give a significant contribution in protecting his community from an intolerant ideology. 
Achmad Zainal Arifin

\section{BIBLIOGRAPHY}

Ahnaf, Muhammad Iqbal et al., Politik Lokal dan Konflik Keagamaan: Pilkada dan struktur kesempatan politik dalam konflik. keagamaan di Sampang, Bekasi, dan Kupang, Yogyakarta: Center for Religious \& Cross-Cultural Studies UGM, 2015.

Asfar, Muhammad (ed.), Islam Lunak, Islam Radikal: Pesantren, Terorisme dan Bom Bali, Surabaya: Pusat Studi Demokrasi dan HAM (PuSDeHAM) \& JP Press, 2003.

Azra, Azyumardi, The Origins of Islamic Reformism in Southeast Asia: Networks of Malay-Indonesian and Middle Eastern "Ulama" in the Seventeenth and Eighteenth Centuries, Crows Nest, NSW: Asian Studies Association of Australia in association with Allen \& Unwin and University of Hawaii Press, 2004.

Badan Pusat Statistik Sleman, Godean dalam Angka, Sleman: BPS Kabupaten Sleman, 2012.

Bagir, Zainal Abidin et al., Laporan Tahunan Kehidupan Beragama di Indonesia, Yogyakarta: CRCS UGM, 2008.

----, Laporan Tahunan Kehidupan Beragama di Indonesia, Yogyakarta: CRCS UGM, 2009.

----, Laporan Tahunan Kehidupan Beragama di Indonesia, Yogyakarta: CRCS UGM, 2010.

----, Laporan Tahunan Kehidupan Beragama di Indonesia, Yogyakarta: CRCS UGM, 2011.

----, Laporan Tahunan Kehidupan Beragama di Indonesia, ed. by Suhadi Cholil, Yogyakarta: CRCS UGM, 2012.

Barton, Greg, Indonesia's Struggle: Jemaah Islamiyah and the Soul of Islam, Sydney: UNSW Press, 2004.

Effendy, Bahtiar and Soetrisno Hadi (eds.), Agama dan Radikalisme di Indonesia, Jakarta: Nuqtah, 2007.

Endraswara, Suwardi, Etika Hidup Orang Jawa: Pedoman Beritiket dalam Menjalani Kehidupan Sehari-hari, Yogyakarta: Narasi, 2010.

Fealy, Greg, "Islamic Radicalism in Indonesia: The Faltering Revival?", in Southeast Asian Affairs, vol. 2004, Singapore: ISEAS-Yusof Ishak 
Defending Traditions, Countering Intolerant Ideology

Institute, 2004.

Hasan, Noorhaidi, Laskar Jihad: Islam, Militancy, and the Quest for Identity in Post-New Order Indonesia, Ithaca, N.Y: Cornell University Pres, 2006.

----, "The Salafi Madrasas of Indonesia", in The Madrasa in Asia: Political Activism and Transnational Linkages, ed. by Farish A. Noor, Yōgīndar Sikkand, and Martin van Bruinessen, Amsterdam: Amsterdam University Press, 2008.

Hasymy, A., Sejarah Masuk dan Berkembangnya Islam di Indonesia: Kumpulan Prasaran pada Seminar di Aceh, Medan: Alma’arif, 1981.

Jamhari and Jajang Jahroni, Gerakan Salafi Radikal di Indonesia, Jakarta: Raja Grafindo Persada, 2004.

Jurdi, Syarifuddin, Sejarah Wahdah Islamiyah: Sebuah Geliat Ormas Islam di Era Transisi, Yogyakarta: Kreasi Wacana, 2007.

Machmudi, Yon, Islamising Indonesia: The Rise of Jemaah Tarbiyah and the Prosperous Justice Party (PKS), Canberra: ANU E Press, 2008.

Magnis-Suseno, Franz and S. Reksosusilo, Etika Jawa dalam Tantangan: Sebuah Bunga Rampai, Yogyakarta: Yayasan Kanisius, 1983.

Mujahid, Mas'ud Izzul, Vonis Kafir: Antara Berlebih-lebihan \& Ketidaktegasan, 1st edition, Solo: Jazera, 2010.

Mulkhan, Abdul Munir, “Gerakan 'Pemurnian Islam' di Pedesaan: Kasus Muhammadiyah Kecamatan Wuluhan, Jember, Jawa Timur”, Ph.D. Dissertation, Yogyakarta: Universitas Gadjah Mada, 1999.

Musta'in, Ahmad Muntaha Al-Bari et al., Menjawab Vonis Bid'ah: Kajian Pesantren, Tradisi \& Adat Masyarakat, 1st edition, Kediri: Pustaka Gerbang Lama, 2010.

Musyarof, Ibtihadj, Islam Jawa, Yogyakarta: Tugu, 2006.

Najib, Agus Moh and Yudian Wahyudi (eds.), Gerakan Wahabi di Indonesia: Dialog dan Kritik, 1st edition, Yogyakarta: Bina Harfa, 2009.

Nashir, Haedar, Gerakan Islam Syari'at: Reproduksi Salafyah Ideologis Di Indonesia, Jakarta: Pusat Studi Agama dan Peradaban Muhammadiyah, 2007.

Pranowo, M. Bambang, Memahami Islam Jawa, Tangerang: Pustaka Alvabet and Indonesian Institute for Society Empowerment / INSEP, 2009. 
Rubaidi, A., Radikalisme Islam, Nabdlatul Ulama \& Masa Depan Moderatisme Islam Di Indonesia, Yogyakarta: Logung Pustaka, 2008.

Sholikhin, Muhammad, Ritual dan Tradisi Islam Jawa: Ritual-ritual dan tradisi-tradisi tentang kehamilan, kelabiran, pernikahan, dan kematian dalam kehidupan sehari-hari masyarakat Islam Jawa, Yogyakarta: Narasi, 2010.

Turmudi, Endang and M. Riza Sihbudi (eds.), Islam dan Radikalisme di Indonesia, Jakarta: LIPI Press, 2005.

Vicziany, Marika and David Wright-Neville (eds.), Islamic Terrorism in Indonesia: Myths and Realities, Clayton, Vict.: Monash University Press, 2006.

Weber, Max, Economy and Society: An Outline of Interpretive Sociology, ed. by Guenther Roth and Claus Wittich, trans. by Ephraim Fischoff, New York: Bedminster Press, 1968.

----, On Charisma and Institution Building: Selected Papers, ed. by S.N. Eisenstadt, Chicago: University of Chicago Press, 1968. 